\title{
Immuno-Modulatory Effects of Bacteriocin-Producing Pediococcus pentosaceus JWS 939 in Mice
}

\author{
Hyun Jong Choi ${ }^{1}$, Ji Ye Kim¹, Myeong Su Shin ${ }^{1,3}$, Sang Myeong Lee ${ }^{2}$, and Wan Kyu Lee ${ }^{1 *}$ \\ ${ }^{1}$ College of Veterinary Medicine and Research Institute of Veterinary Medicine, \\ Chungbuk National University, Cheongju 361-763, Korea \\ ${ }^{2}$ Division of Biotechnology, College of Environmental \& Bioresource Sciences, Chonbuk National University, \\ Iksan 570-752, Korea \\ ${ }^{3}$ Korea Bio Science Research Institute of Organic Bio Tech Co., Ltd., Jincheon 365-861, Korea
}

\begin{abstract}
Pediococcus pentosaceus JWS 939 (JWS 939) is a nonpathogenic bacteriocin-producing probiotic isolated from the duck intestine. This study assessed the immunomodulatory effects of JWS 939 and compared them with those of Lactobacillus rhamnosus GG (LGG), a well-known immune enhancer. The immune-enhancing effects of JWS 939 were measured by measuring the production of nitric oxide (NO) and cytokines in C57BL/6 mouse peritoneal macrophages. In addition, to assess the immune enhancement abilities of JWS 939, in vivo, a Listeria monocytogenes challenge mice model was used. The results showed that heat-killed JWS 939 induced more NO and interleukin (IL)-1 $\beta$ production in mouse peritoneal macrophages than in LGG, and that oral administration of viable JWS 939 in mice increased more NO, IL-1 $\beta$, and tumor necrosis factor (TNF)- $\alpha$ level than in LGG in serum upon L. monocytogenes challenge. In addition, mice fed with JWS 939 had a longer survival time after lethal challenge with $L$. monocytogenes, and these effects were stronger than those induced by LGG. Collectively, P. pentosaceus JWS 939 is a remarkable strain that, by releasing bacteriocin and enhancing host immune responses, may have potential as a duck feed additive to suppress pathogens.
\end{abstract}

Key words: lactic acid bacteria, immune response, bacteriocin(s), Listeria, macrophage(s)

\section{Introduction}

Pediococcus pentosaceus is a Gram-positive probiotic that is commonly found in cheese and yogurt and is reported to be a beneficial microbe (Haakensen et al., 2009). This probiotic produces various bacteriocins, called pediocins, and the bacteriocin produced by P. pentosaceus inhibits growth of pathogenic bacteria such as Clostridium perfringens and Listeria monocytogenes (Daeschel and Klaenhammer 1985; Wu et al., 2004). P. pentosaceus also has immunomodulatory effects. Earlier studies reported that $P$. pentosaceus induces interferon- $\gamma$ and interleukin (IL)-12, and suppresses IL-4 in mouse spleen cells or peritoneal macrophages (Igarashi, 2010; Jonganurakkun et al., 2008).

Macrophages are phagocytes that have differentiated

\footnotetext{
*Corresponding author: Wan-Kyu Lee, College of Veterinary Medicine and Research Institute of Veterinary Medicine, Chungbuk National University, Cheongju 361-763, Korea. Tel: 82-43-2612960, Fax: 82-43-267-3150, E-mail: wklee@cbu.ac.kr
}

from monocytes and exist within host tissues. These cells also play an important role in host immune responses (van Furth et al., 1972). Various stimuli including bacteria, lipopolysaccharides (LPS), lymphokines, and interferons activate macrophages, and activated macrophages regulate host immunity (Lorsbach et al., 1993). Nitric oxide (NO) and proinflammatory cytokines such as IL-1 $\beta$ and tumor necrosis factor- $\alpha$ (TNF- $\alpha$ ) are produced by macrophages (Marin et al., 1997; Schereiber et al., 1985). NO is a short-lived mediator that either kills or restrains the growth of bacteria and tumor cells (Snyder and Bredt, 1992). IL-1 $\beta$ is a proinflammatory cytokine that triggers a cascade of immune responses to induce secretion of other cytokines and chemokines. It also induces a variety of cellular responses such as cell proliferation, differentiation, and apoptosis (Dinarello, 1996). TNF- $\alpha$ has a broad spectrum of systemic and cellular immunity activities and, also, suppresses intracellular pathogens and controls inflammatory processes to enhance resistance to infectious disease (Derouich-Guergour et al., 2001).

Bacteriocins are substances from bacteria and produce 
antimicrobial effects by suppressing the synthesis of the target bacteria's inner membrane. Bacteriocins produced by lactic acid bacteria have a particular ability to kill pathogenic bacteria such as Listeria monocytogenes or Clostridium perfringens (Chanos and Williams, 2011; Grilli et al., 2009). Therefore, bacteriocin-producing lactic acid bacteria may be an effective substitute for antibiotics (Nes et al., 2007).

Bacteriocin-producing P. pentosaceus JWS 939 (JWS 939) has been isolated from the intestines of ducks (Shin et al., 2007). Bacteriocin produced by JWS 939 is effective in killing L. monocytogenes and Streptococcus mutans in vitro and this activity is not destroyed within a $\mathrm{pH}$ range of 2.0 to 9.0 or by heating $\left(95^{\circ} \mathrm{C}\right.$ for $\left.30 \mathrm{~min}\right)$. It also retains this ability following exposure to enzymes such as catalase and amylase (Shin et al., 2007).

The present study investigated the immune effects of bacteriocin-producing JWS 939. The JWS 939 was heatkilled and its immune effects in vitro, based on $\mathrm{NO}$ and inflammatory cytokines productions on C57BL/6 mouse peritoneal macrophages were examined. Thereafter, a $L$. monocytogenes-infected mice model was used to examine the protective effects of JWS 939 in vivo. The in vitro and in vivo effects were compared with those mediated by Lactobacillus rhamnosus GG (LGG), a well-known probiotic with immune enhancement effects.

\section{Materials and Methods}

\section{Microorganism preparation}

Probiotics (JWS 939 and LGG) were grown in MRS broth (BD, USA) at $37^{\circ} \mathrm{C}$ for $24 \mathrm{~h}$, and viable probiotic cells were counted in an MRS plate. Then, the probiotic cells were collected by centrifugation at $12,000 \mathrm{rpm}$ for $10 \mathrm{~min}$ at $4^{\circ} \mathrm{C}$ and the supernatant discarded. Cell pellets were washed twice and resuspended in $0.01 \mathrm{M}$ sterile phosphate buffered saline (PBS; pH 7.2). For in vitro experiments, probiotic cells were killed by heating at $110^{\circ} \mathrm{C}$ for $15 \mathrm{~min}$ and stored at $-20^{\circ} \mathrm{C}$ until use. All probiotic stocks were diluted to $5 \times 10^{8} \mathrm{CFU} / \mathrm{mL}$ for high concentration dosage or $1 \times 10^{8} \mathrm{CFU} / \mathrm{mL}$ for low concentration dosage. For the in vivo tests, the viable probiotic cell pellets were concentrated to $1 \times 10^{10} \mathrm{CFU} / \mathrm{mL}$ in PBS containing $10 \%$ skim milk.

L. monocytogenes BA00092 (porcine origin; National Veterinary Research \& Quarantine Service of Korea, Korea) were grown overnight in $\mathrm{BHI}$ broth (BD, USA) at $37^{\circ} \mathrm{C}$ and the number of viable bacterial cells was counted in a BHI plate. Cell pellets were collected by centrifugation at $12,000 \mathrm{rpm}$ for $5 \mathrm{~min}$ at $4^{\circ} \mathrm{C}$; subsequently, the cells were washed twice and diluted to $2 \times 10^{6} \mathrm{CFU} / \mathrm{mL}$ in PBS.

\section{Isolation of murine peritoneal macrophages}

Mouse peritoneal macrophages were isolated according to the method of Zhang et al. (2008). Briefly, Brewer thioglycollate medium (Sigma, USA) was injected via an intra-peritoneal (i.p.) route to C57BL/6 mouse. After 4-5 $\mathrm{d}$, peritoneal macrophages were collected from the peritoneal cavities of the treated mice. Mice were euthanized with $\mathrm{CO}_{2}$ and $5 \mathrm{~mL}$ PBS were injected into the peritoneal cavity. Then, the cavity fluid was aspirated and centrifuged at $1,500 \mathrm{rpm}$ for $8 \mathrm{~min}$ at $4^{\circ} \mathrm{C}$. The cell pellet was washed twice with PBS and counted in a hematocytometer, cell viability was checked before they were diluted to $1 \times 10^{6}$ cells $/ \mathrm{mL}$ in a RPMI 1640 medium (Sigma, USA) supplemented with $10 \%(\mathrm{v} / \mathrm{v})$ FBS (Invitrogen, USA) along with, $100 \mathrm{mg} / \mathrm{mL}$ streptomycin and $100 \mathrm{U} / \mathrm{mL}$ penicillin (Invitrogen, USA).

\section{Activation of peritoneal macrophages}

Peritoneal macrophages $\left(5 \times 10^{5}\right.$ cells/well $)$ were cultured in triplicate and heat-killed probiotics $(100 \mu \mathrm{L}$ containing $5 \times 10^{7} \mathrm{CFU} / \mathrm{mL}$ or $1 \times 10^{7} \mathrm{CFU} / \mathrm{mL}$ of LGG or JWS 939) were added to the wells. The probiotic concentrations were such that the macrophages were exposed to either 20 or 100 probiotic cells per macrophage, at $37^{\circ} \mathrm{C}$ with $5 \% \mathrm{CO}_{2}$. Instead of probiotics, PBS was only added to wells as a negative control, and positive control was added LPS (100 or $500 \mathrm{ng} / \mathrm{mL}$; Sigma, USA) in PBScontaining wells. After $24 \mathrm{~h}$, the culture supernatants were collected and the concentrations of NO and cytokines (IL-1 $\beta$ and TNF- $\alpha$ ) in the supernatants were determined.

\section{Measurement of NO}

NO levels of macrophages were measured using Griess reagent (Promega, USA). Briefly, $50 \mu \mathrm{L}$ of macrophage culture supernatant were mixed (in triplicate) with an equal volume of $1 \%$ sulfanilamide in $5 \%$ phosphoric acid and $0.1 \% \mathrm{~N}$-1-naphylethylenediamine dihydrochloride at room temperature for $10 \mathrm{~min}$ in the dark. Absorbance was then measured at $540 \mathrm{~nm}$ by using a microplate reader (Molecular Devices, USA). The production levels of NO were calculated from a standard curve for a nitrite standard (0-100 $\mu \mathrm{M}$ sodium nitrite). 


\section{Measurement of cytokines}

Cytokines (IL-1 $\beta$ and TNF- $\alpha$ ) were measured using ELISA kits (BD, USA) in accordance with the manufacturer's instructions. Samples were assayed in triplicate and absorbance read at $450 \mathrm{~nm}$ in a microplate reader. Cytokine levels were then calculated from a standard curve of the cytokine standards $(0-2,000 \mathrm{pg} / \mathrm{mL}$ for IL$1 \beta ; 0-1,000 \mathrm{pg} / \mathrm{mL}$ for TNF- $\alpha$ ).

\section{Animals and $L$. monocytogenes challenge methods}

Female 7-9 wk old BALB/c mice were purchased from Nara Biotech (Korea) and were housed under $12 \mathrm{~h}$ light/ dark cycles with a commercial rodent diet and water $\mathrm{ad}$ libitum. Mice were given a daily dose of $1 \times 10^{9} \mathrm{CFU}$ of viable LGG or viable JWS 939 in $100 \mu \mathrm{L}$ PBS containing $10 \%$ skim milk via a gastric tube for $2 \mathrm{wk}$. The negative control group (NC) and positive control group (PC) was given $100 \mu \mathrm{L}$ PBS containing $10 \%$ skim milk without probiotics. After $2 \mathrm{wk}$, both the probiotics-fed groups and the PC were injected with L. monocytogenes $\left(1.2 \times 10^{5}\right.$ CFU in $100 \mu \mathrm{L}$ PBS) via the tail vein. The $\mathrm{NC}$ was injected with $100 \mu \mathrm{L}$ PBS without L. monocytogenes.

\section{Collection of serum and tissue samples for immu- nological and bacteriological analyses}

Three days after infection with L. monocytogenes, 7 mice per group were euthanized and their body weight determined. In addition, serum was collected and their livers and spleens were weighed. Mice sera were analyzed for levels of NO and cytokines (IL-1 $\beta$ and TNF- $\alpha$ ). Liver and spleen weights were expressed relative to body weight. The liver was aseptically homogenized by passage through a $70 \mu \mathrm{m}$ nylon mesh (Fisher Scientific, USA); subsequently, the number of viable L. monocytogenes cells was counted in a BHI plate. The results were expressed as log-based data.

\section{Survival analysis}

Ten mice per group were used for survival time analysis. Mice were fed probiotics or PBS containing 10\% skim milk for $2 \mathrm{wk}$ and then challenged with L. monocytogenes as described above. Survival time was monitored every $8 \mathrm{~h}$ until death.

\section{Statistical analysis}

SPSS for Windows version 12.0 (SPSS Inc., USA) was used for statistical analysis of data. Significant differences between groups were tested by ANOVA and compared using Tukey's and Duncan's multiple range tests ( $p$
$<0.05$ ), except for survival time analysis. Survival time was analyzed by using Student's t-test $(p<0.05)$.

\section{Results}

\section{NO and cytokines production of peritoneal mac- rophages in vitro}

To examine the immunomodulatory effects of JWS 939, the production of NO and cytokines (IL-1 $\beta$ and TNF- $\alpha$ ) triggered by heat-killed JWS 939 was measured in vitro using peritoneal macrophages. Although NO production was induced by both JWS 939 and LGG heatkilled probiotics, the NO production from JWS 939 treatment was greater than that from LGG (Fig. 1A). Productions of $\mathrm{NO}$ in the low concentration $\left(1 \times 10^{7} \mathrm{CFU} / \mathrm{mL}\right)$ of JWS 939 and in both the low and high concentration of LGG were not statistically different from that in the PBS control. However, the high concentration $\left(5 \times 10^{7} \mathrm{CFU} /\right.$ $\mathrm{mL}$ ) of JWS 939 induced NO production of $3.78 \pm 0.07$ $\mu \mathrm{M} / \mathrm{mL}$, which was significantly higher than the production in the $100 \mathrm{ng} / \mathrm{mL}$ LPS-treated positive control.

JWS 939 and LGG increased IL-1 $\beta$ production in a dose-dependent manner (Fig. 1B) with production from JWS 939 treatment higher than that from LGG treatment. IL- $1 \beta$ was barely detectable in low dose $\left(1 \times 10^{7} \mathrm{CFU} / \mathrm{mL}\right)$ LGG-treated macrophages. LGG at the high dosage $(5 \times$ $10^{7} \mathrm{CFU} / \mathrm{mL}$ ) induced $222.32 \pm 4.87 \mathrm{pg} / \mathrm{mL}$ of IL- $1 \beta$ production, which was significantly lower than that induced by JWS 939 at $1 \times 10^{7} \mathrm{CFU} / \mathrm{mL}(1683.64 \pm 35.00 \mathrm{pg} / \mathrm{mL})$. Moreover, JWS 939 at the high dosage $\left(5 \times 10^{7} \mathrm{CFU} / \mathrm{mL}\right)$ induced IL-1 $\beta$ production at a level significantly higher than that induced by $500 \mathrm{ng} / \mathrm{mL}$ LPS $(2845.45 \pm 97.71 \mathrm{pg} /$ $\mathrm{mL}$ vs. $2097.97 \pm 15.44 \mathrm{pg} / \mathrm{mL}$, respectively).

The level of TNF- $\alpha$ production showed a different pattern (Fig. 1C). LGG induced TNF- $\alpha$ production in dosedependent manner and triggered significantly greater TNF$\alpha$ synthesis than $500 \mathrm{ng} / \mathrm{mL}$ LPS. On the other hand, the low concentration $\left(1 \times 10^{7} \mathrm{CFU} / \mathrm{mL}\right)$ JWS 939 dosage induced higher levels of TNF- $\alpha$ than the same concentration of LGG or $500 \mathrm{ng} / \mathrm{mL}$ LPS, but the JWS 939 and LGG difference was not statistically significant. Moreover, JWS 939 did not show a dose-dependent effect on TNF- $\alpha$ production.

\section{Immune effects of JWS 939 in L. monocytogenes challenge model}

To assess whether JWS 939 stimulates macrophages in vivo and protects the host from acute lethal bacterial infection, a well-established $L$. monocytogenes infection 

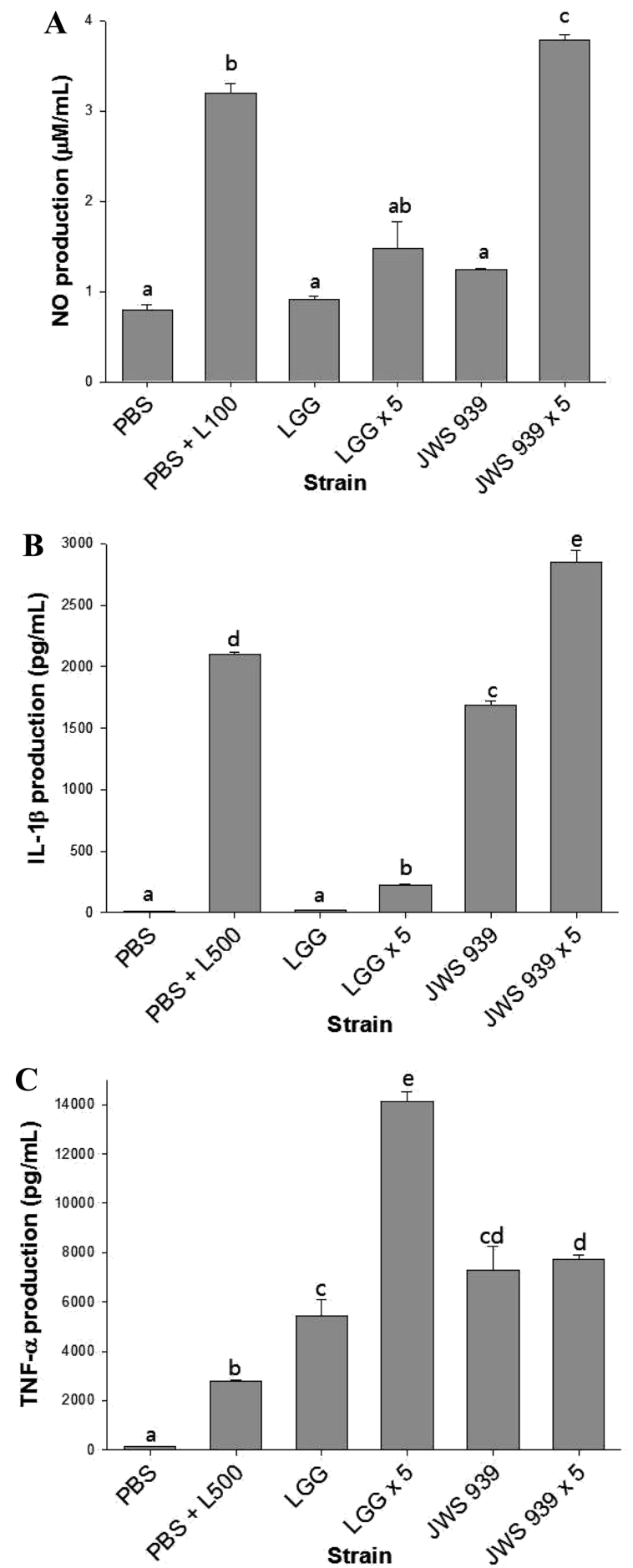

Fig. 1. Nitric oxide (NO) (A), IL-1 $\beta$ (B), and TNF- $\alpha$ (C) production by murine peritoneal macrophages induced by two concentrations of heat-killed $L$. rhamnosus GG (LGG) and P. pentosaceus JWS 939 (JWS 939). Murine peritoneal macrophages $\left(5 \times 10^{5}\right.$ cells $\left./ \mathrm{mL}\right)$ were stimulated with probiotics or PBS for $24 \mathrm{~h}$. LGG and JWS 939 concentrations were $1 \times 10^{7} \mathrm{CFU} / \mathrm{mL}$. LGG $\times 5$ and JWS $939 \times$ 5 concentrations were $5 \times 10^{7} \mathrm{CFU} / \mathrm{mL}$. L100 or L500 means LPS at $100 \mathrm{ng} / \mathrm{mL}$ or $500 \mathrm{ng} / \mathrm{mL}$, respectively. Data are mean \pm SD values of triplicates. Different superscript letters $(\mathrm{a}, \mathrm{b}, \mathrm{c}$ and $\mathrm{d})$ indicate statistical differences as determined by ANOVA $(p<0.05)$. model was used. Viable JWS 939 or LGG cells were orally administrated to female BALB/c mice daily for $2 \mathrm{wk}$ prior to $L$. monocytogenes challenge.

All three L. monocytogenes challenge groups ( $\mathrm{PC}$, LGG-fed, and JWS 939-fed mice) lost body weight compared to that in the NC (no L. monocytogenes infection); however, no differences in body weights were observed between the three L. monocytogenes challenge groups (Table 1). The three L. monocytogenes challenge groups had significantly higher relative liver weights than that in the NC. In addition, LGG-fed and JWS 939-fed groups had significantly heavier relative liver weight than that in the PC. With regard to relative spleen weights, it was not significantly higher in the JWS 939-fed group than in the $\mathrm{NC}$, but the relative spleen weights in the PC and LGGfed groups were significantly higher than that in the NC.

Both of the probiotics-fed groups had significantly lower numbers of viable L. monocytogenes in their livers compared to the PC (Fig. 2), The JWS 939-fed mice had fewer bacteria in the liver than the LGG-fed mice, but the difference was not significant. Livers from the PC contained an average of $4.3 \times 10^{8} \mathrm{CFU} / \mathrm{g} L$ monocytogenes cells; those of the JWS 939-fed and LGG-fed groups contained $89 \%$ and $87 \%$ fewer bacteria, respectively.

The level of NO in the sera of JWS 939-fed mice was significantly higher than that in the NC $(8.45 \pm 0.73 \mu \mathrm{M}$ vs. $4.70 \pm 0.64 \mu \mathrm{M}$, respectively), but the NO levels in the PC $(7.08 \pm 1.37 \mu \mathrm{M})$ and LGG-fed mice $(6.96 \pm 0.67 \mu \mathrm{M})$ were not significantly different from that in the NC. The NO level in the JWS 939-fed group was higher than that in any of the other groups, but it was only statistically different from that in the NC (Fig. 3A).

Table 1. Effect of Pediococcus pentosaceus JWS 939 on the body weight and relative liver and spleen weights of mice 3 d after Listeria monocytogenes challenge

\begin{tabular}{lccc}
\hline \hline Group & $\begin{array}{c}\text { Body weight } \\
(\mathrm{g})\end{array}$ & $\begin{array}{c}\text { Liver/BW } \\
(\mathrm{g} / \mathrm{kg})\end{array}$ & $\begin{array}{c}\text { Spleen/BW } \\
(\mathrm{g} / \mathrm{kg})\end{array}$ \\
\hline $\mathrm{NC}$ & $18.38 \pm 0.27^{\mathrm{a}}$ & $46.99 \pm 1.53^{\mathrm{a}}$ & $5.47 \pm 0.08^{\mathrm{a}}$ \\
PC & $15.31 \pm 0.26^{\mathrm{b}}$ & $69.56 \pm 2.01^{\mathrm{b}}$ & $7.35 \pm 0.49^{\mathrm{b}}$ \\
LGG & $14.67 \pm 0.40^{\mathrm{b}}$ & $70.45 \pm 0.71^{\mathrm{c}}$ & $6.81 \pm 0.22^{\mathrm{b}}$ \\
JWS939 & $14.30 \pm 0.21^{\mathrm{b}}$ & $71.79 \pm 1.30^{\text {cd }}$ & $5.21 \pm 0.21^{\mathrm{a}}$ \\
\hline
\end{tabular}

Data represent the mean \pm SE of seven mice in each group. Different superscript letters $\left({ }^{\mathrm{a}, \mathrm{b}, \mathrm{c} \text { and }} \mathrm{d}\right)$ indicate the statistical differences determined by ANOVA $(p<0.05)$. NC, normal control group (no probiotic-feeding and no L. monocytogenes infection); PC, positive control group (no probiotic-feeding and infected with $L$. monocytogenes); LGG, Lactobacillus rhamnosus GG-fed and infected with L. monocytogenes group; JWS 939, Pediococcus pentosaceus JWS 939-fed and infected with L. monocytogenes group. 


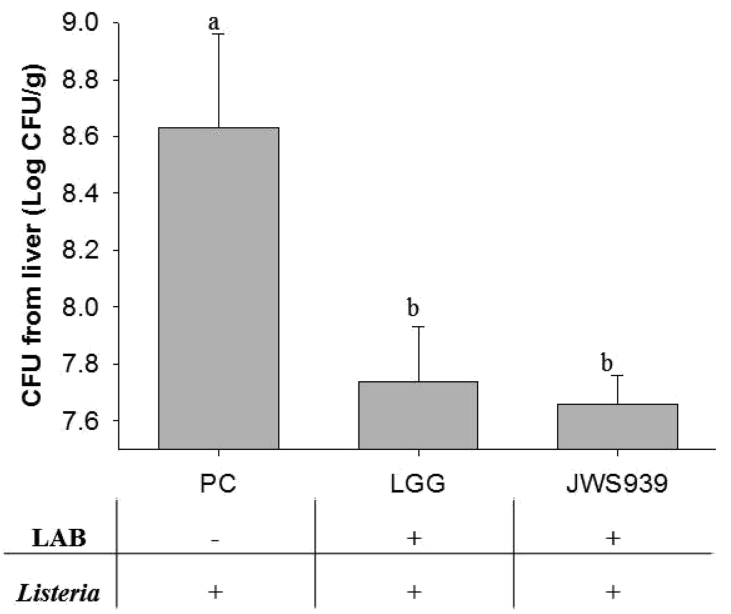

Fig. 2. Viable cells of $L$. monocytogenes in liver of BALB/c mice in the L. monocytogenes challenge model. Data represent $\log$ data of mean $\pm \mathrm{SE}$ of seven mice in each group. PC, positive control group (no probiotic-feeding and infected with $L$. monocytogenes). LGG, L. rhamnosus GG-fed and infected with $L$. monocytogenes; JWS 939, $P$. pentosaceus JWS 939-fed and infected with $L$. monocytogenes. Different superscript letters $\left({ }^{\mathrm{a} a n d} \mathrm{~b}\right)$ indicate statistical differences as determined by ANOVA $(p<0.05)$

The levels of IL- $1 \beta$ and TNF- $\alpha$ in the serum showed a similar tendency. Only the JWS 939-fed mice showed significant differences from the other groups (Fig. 3B and C). Levels of IL-1 $\beta$ and TNF- $\alpha$ in the LGG-fed group were not significantly different from those in the $\mathrm{NC}$ or PC. On the other hand, JWS 939-fed mice induced 1082.57 $\pm 298.12 \mathrm{pg} / \mathrm{mL}$ of IL-1 $\beta$ and $895.67 \pm 280.54 \mathrm{pg} / \mathrm{mL}$ of TNF- $\alpha$ production, showing significant differences from all other groups.

JWS 939-fed mice survived longer than those in the PC and LGG-fed groups (Table 2). Mice in the NC did not die during the experimental period, but all mice in the PC and probiotics-fed groups died within $150 \mathrm{~h}$ after $L$. monocytogenes challenge. Mean survival time of the LGGfed group was not significantly different from that in the PC, but that in the JWS 939-fed group was significantly different from survival in the PC.

\section{Discussion}

Probiotics are widely used as food supplements or therapeutic agents because they enhance host immune responses by increasing the production of $\mathrm{NO}$ and cytokines in macrophages (Saarela et al., 2000; Tejada-Simon and Peska, 1999). Here, JWS 939, isolated from duck intestines, was examined to assess its immune enhancing effects. To that end, levels of NO and inflammatory cytok-
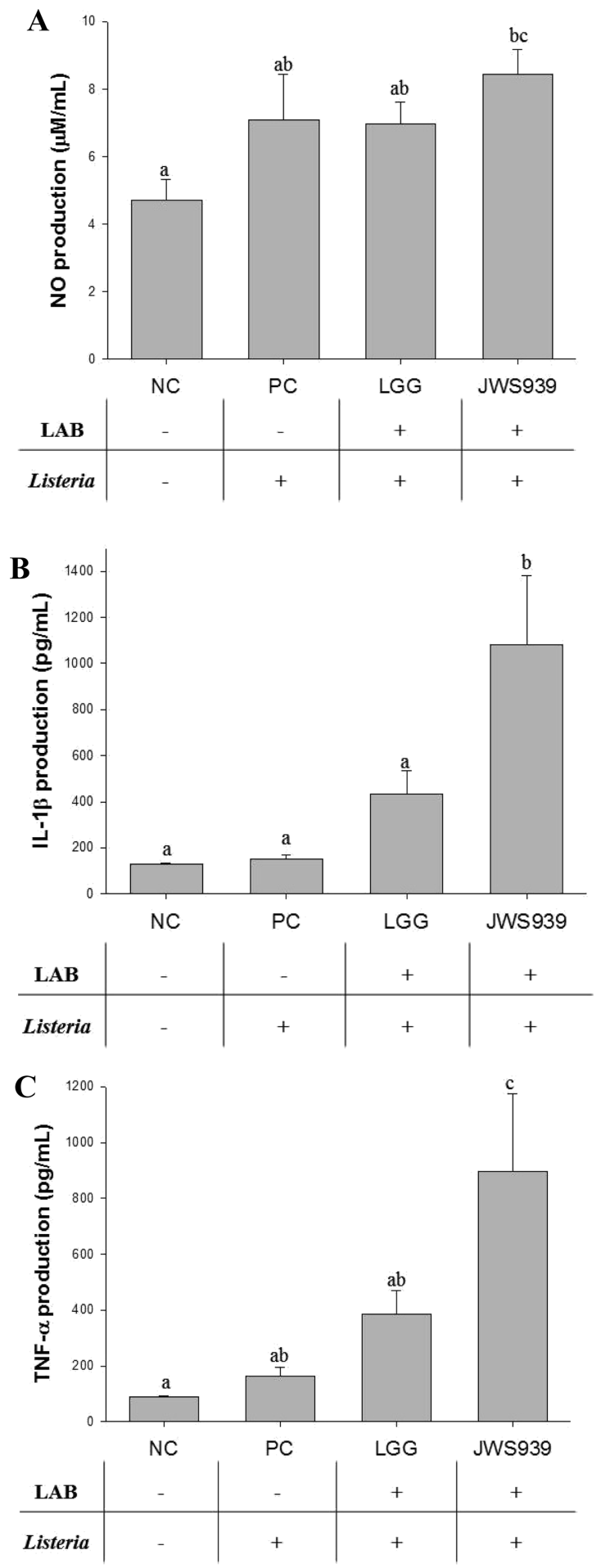

Fig. 3. Nitric oxide (A), IL-1 $\beta$ (B), and TNF- $\alpha$ (C) production in BALB/c mice sera in the $L$. monocytogenes challenge model. Data represent mean $\pm \mathrm{SE}$ of seven mice in each group. NC, normal control group (no probiotic-feeding and no L. monoctytogenes infection); PC, positive control group (no probiotic-feeding and infected with $L$. monocytogenes). LGG, L. rhamnosus GG-fed and infected with L. monocytogenes; JWS 939, P. pentosaceus JWS 939-fed and infected with L. monocytogenes. Different superscript letters $(\mathrm{a}, \mathrm{b}$ and $\mathrm{c})$ indicate statistical differences as determined by ANOVA $(p<0.05)$. 
Table 2. Mean survival time of mice fed LGG or JWS 939 and infection to L. monocytogenes

\begin{tabular}{|c|c|}
\hline Group & Survival time (h) \\
\hline NC (no probiotic-feeding and no L. monocytogenes infection) & - \\
\hline PC (no probiotic-feeding and infected with L. monocytogenes) & $102.00 \pm 3.86$ \\
\hline LGG (Lactobacillus rhamnosus GG-fed and infected with L. monocytogenes) & $112.95 \pm 5.42$ \\
\hline JWS 939 (Pediococcus pentosaceus JWS 939- fed and infected to L. monocytogenes) & $116.14 \pm 5.32 *$ \\
\hline
\end{tabular}

Data are mean \pm SE of 10 mice in each group. All mice of NC did not die in $160 \mathrm{~h} . *^{*}$ indicates the statistical different with PC as determined by student's $t$-test $(p<0.05)$.

ines were measured in mouse peritoneal macrophages and in a $L$. monocytogenes infection model. The mediation of immune effects by JWS 939 was compared with that by LGG, a probiotic strain known to have immunomodulatory effects. LGG has been shown to induce immune cells to produce $\mathrm{NO}$ and inflammatory cytokines. For example, dendritic cells stimulated by LGG have shown increased production of IL-12, IL-17, and TNF- $\alpha$ (Mileti et al., 2009). Another study reported that macrophages released both NO and IFN- $\gamma$ when co-cultured with LGG and a pathogenic antigen (Ghadimi et al., 2010).

Here, heat-killed JWS 939 stimulated mouse peritoneal macrophages to increase the production of NO, IL- $1 \beta$, and TNF- $\alpha$ in vitro experiment. Moreover, these immune effects were stronger than that induced by LGG, except for TNF- $\alpha$ production. For the in vitro experiments, JWS 939 and LGG were killed by heating in order to investigate the effect on macrophages of killed probiotics, and to prevent macrophage cell death caused by overgrowth of the probiotic cells and the resulting acidic $\mathrm{pH}$. Heat-killed probiotics have been shown to activate macrophages and induce cytokine production (Lin et al., 2007; Nonaka et al., 2008); in addition, earlier study has shown that heatkilled LGG was as effective as viable LGG (Korhonen $e t$ al., 2001).

It has been reported that probiotics prevent infectious disease in mice. Mice infected with Salmonella Typhimurium or L. monocytogenes were protected by L. rhamnosus or Lactobacillus casei (Gill et al., 2001; Nomoto et al., 1985). Also, P. pentosaceus protected against the invasion of Salmonella in mice (Chiu et al., 2008). Here, to evaluate the protective effects of JWS 939 against infection by pathogens, a L. monocytogenes challenge model was used. L. monocytogenes is a food-borne pathogen that causes listeriosis and is widely used in experimental model studies of host immune responses to bacterial infection. The coordinated action of various immune cells and cytokines of a host's immune system is required to protect against L. monocytogenes infection (Edelson and Unanue, 2000; Milon, 1997).
Here, we found that relative liver and spleen weights of mice increased following L. monocytogenes infection. Relative spleen weights were increased in both the PC and LGG-fed groups, but not in JWS 939-fed group. A decrease in relative spleen weight is indicative of increased host resistance; for example, Lactobacillus plantarum reduced the spleen weight in L. monocytogenes-infected mice and increased the survival rate of the mice (Puertollano et al., 2008). Here, the LGG-fed and JWS 939-fed groups showed relatively heavier livers than the PC, a result similar to that in an earlier study in which oral administration of probiotics had increased liver weight in female rats (Tsai et al., 2004).

JWS 939 increased NO and inflammatory cytokines (IL-1 $\beta$ and TNF- $\alpha$ ) levels in serum more than did LGG after $L$. monocytogenes infection. NO and cytokines produce beneficial effects by maintaining a balance within the immune system and by protecting against infections (Park et al., 1999). Moreover, JWS 939 decreases numbers of viable $L$. monocytogenes in mice liver more than does LGG. JWS 939 activated macrophages of mice such as in vitro experiment, as a result of that activation; the numbers of viable $L$. monocytogenes was lower in the JWS 939-fed group than in the LGG-fed group. Consequentially, we suggest that JWS 939 increases host resistance to L. monocytogenes.

JWS 939-fed mice had a significantly longer survival time that of the PC; regardless, none of the mice infected with $L$. monocytogenes, including the JWS 939-fed group, survived the infection. We expected survival time to be higher in the JWS 939-fed group, but the observed difference was not as dramatic as expected. Perhaps, if a lower dose of L. monocytogenes or a less pathogenic strain is used, the survival rate and survival time difference may be more dramatic. Moreover, mice were infected with $L$. monocytogenes via an intra-venous (i.v.) route to evaluate the immune effect of JWS 939 in the absence of an antimicrobial effect of the bacteriocin produced by JWS 939, and most recent studies used the i.v. route. If $L$. monocytogenes infection was via the oral route, JWS 939 may 
show a much stronger protective effect, because JWS 939 has the ability to suppress $L$. monocytogenes via a direct bacteriocin-based bactericidal effect and can indirectly and simultaneously stimulate the host's immune system.

When probiotics are used for the same animal species from which they were isolated, they have intestinal adherence, settlement, and safety advantages (Kosin and Rakshit, 2006). Ehrmann et al. (2002) reported that two probiotic strains isolated from duck have potential as effective feed additives in duck. JWS 939 is a non-pathogenic member of duck microflora that has the ability to produce bacteriocin and has immuno-stimulatory effects, both in vitro and in vivo. Feeding a bacteriocin to an animal can enhance its immune responses. For example, broiler chickens have been protected from $C$. perfringens infection by feeding the bacteriocin of $P$. pentosaceus (Grilli et al., 2009). Therefore, JWS 939 may have great potential as a feed supplement that can enhance the immune response in duck; more so, since JWS 939 produces bacteriocin and activates macrophages.

In conclusion, JWS 939 has the ability to induce immune responses both in vitro and in vivo and prolongs mouse survival time after lethal L. monocytogenes infection. Moreover, these effects are stronger than those from LGG. Further studies are needed to determine whether JWS 939 enhances immunity and provides protection against bacterial or viral infections in duck.

\section{Acknowledgment}

This work was supported by a research grant of the Chungbuk National University in 2010.

\section{References}

1. Chanos, P. and Williams, D. R. (2011) Anti-Listeria bacteriocin-producing bacteria from raw ewe's milk in northern Greece. J. Appl. Microbiol. 110, 757-768.

2. Chiu, H. H., Tsai, C. C., Hsih, H. Y., and Tsen, H. Y. (2008) Screening from pickled vegetables the potential probiotic strains of lactic acid bacteria able to inhibit the Salmonella invasion in mice. J. Appl. Microbiol. 104, 605-612.

3. Daeschel, M. A. and Klaenhammer, T. R. (1985) Association of a 13.6-megadalton plasmid in Pediococcus pentosaceus with bacteriocin activity. Appl. Environ. Microbiol. 50, 1538-1541.

4. Derouich-Guergour, D., Brenier-Pinchart, M. P., AmbroiseThomas, P., and Pelloux, H. (2001) Tumour necrosis factor alpha receptors: role in the physiopathology of protozoan parasite infections. Int. J. Parasitol. 31, 763-769.

5. Dinarello, C. A. (1996) Biologic basis for interleukin-1 in disease. Blood 87, 2095-2147.

6. Edelson, B. T. and Unanue, E. R. (2000) Immunity to Listeria infection. Curr. Opin. Immunol. 12, 425-431.

7. Ehrmann, M. A., Kurzak, P., Bauer, J., and Vogel, R. F. (2002) Characterization of lactobacilli towards their use as probiotic adjuncts in poultry. J. Appl. Microbiol. 92, 966-975.

8. Ghadimi, D., de Vrese, M., Heller, K. J., and Schrezenmeir, J. (2010) Lactic acid bacteria enhance autophagic ability of mononuclear phagocytes by increasing Th1 autophagy-promoting cytokine (IFN-gamma) and nitric oxide (NO) levels and reducing Th2 autophagy-restraining cytokines (IL-4 and IL-13) in response to Mycobacterium tuberculosis antigen. Int. Immunopharmacol. 10, 694-706.

9. Gill, H. S., Shu, Q., Lin, H., Rutherfurd, K. J., and Cross, M. L. (2001) Protection against translocating Salmonella typhimurium infection in mice by feeding the immuno-enhancing probiotic Lactobacillus rhamnosus strain HN001. Med. Microbiol. Immunol. 190, 97-104.

10. Grilli, E., Messina, M. R., Catelli, E., Morlacchini, M., and Piva, A. (2009) Pediocin A improves growth performance of broilers challenged with Clostridium perfringens. Poultry Sci. 88, 2152-2158.

11. Haakensen, M., Dobson, C. M., Hill, J. E., and Ziola, B. (2009) Reclassification of Pediococcus dextrinicus (Coster and White 1964) back 1978 (Approved Lists 1980) as Lactobacillus dextrinicus comb. Nov., and emended description of the genus Lactobacillus. Int. J. Syst. Evol. Microbiol. 59, 615-621.

12. Igarashi, T. (2010) Study of the relationship between changes in lactic acid bacterial cell components and stimulation of IL-12 production under salt-stressed conditions. Biosci. Biotechnol. Biochem. 74, 2171-2175.

13. Jonganurakkun, B., Wang, Q., Xu, S. H., Tada, Y., Minamida, K., Yasokawa, D., Sugi, M., Hara, H., and Asano, K. (2008) Pediococcus pentosaceus NB-17 for probiotic use. $J$. Biosci. Bioeng. 106, 69-73.

14. Korhonen, R., Korpela, R., Saxelin, M., Mäki, M., Kankaanranta, H., and Moilanen, E. (2001) Induction of nitric oxide synthesis by probiotic Lactobacillus rhamnosus GG in J774 macrophages and human T84 intestinal epithelial cells. Inflammation 25, 223-232.

15. Kosin, B. and Rakshit, S. K. (2006) Microbial and processing criteria for production of probiotics: a review. Food Technol. Biotechnol. 44, 371-379.

16. Lin, W. H., Yu, B., Lin, C. K., Hwang, W. Z., and Tsen, H. Y. (2007) Immune effect of heat-killed multistrain of Lactobacillus acidophilus against Salmonella typhimurium invasion to mice. J. Appl. Microbiol. 102, 22-31.

17. Lorsbach, R. B., Murphy, W. J., Lowenstein, C. J., Snyder, S. H., and Russell, S. W. (1993) Expression of the nitric oxide synthase gene in mouse macrophages activated for tumor cell killing. Molecular basis for the synergy between interferon-gamma and lipopolysaccharide. J. Biol. Chem. 268, 1908-1913.

18. Marin, M. L., Lee, J. H., Murtha, J., Ustunol, Z., and Pestka, J. J. (1997) Differential cytokine production in clonal mac- 
rophage and T-cell lines cultured with Bifidobacteria. J. Dairy Sci. 80, 2713-2720.

19. Mileti, E., Matteoli, G., Iliev, I. D., and Rescigno, M. (2009) Comparison of the immunomodulatory properties of three probiotic strains of Lactobacilli using complex culture systems: prediction for in vivo efficacy. PLoS One 4, e7056.

20. Milon, G. (1997) Listeria monocytogenes in laboratory mice: a model of short-term infectious and pathogenic processes controllable by regulated protective immune responses. Immunol. Rev. 158, 37-46.

21. Nes, I. F., Diep, D. B., and Holo, H. (2007) Bacteriocin diversity in Streptococcus and Enterococcus. J. Bacteriol. 189, 1189-1198.

22. Nomoto, K., Miake, S., Hashimoto, S., Yokokura, T., Mutai, M., Yoshikai, Y., and Nomoto, K. (1985) Augmentation of host resistance to Listeria monocytogenes infection by Lactobacillus casei. J. Clin. Lab. Immunol. 17, 91-97.

23. Nonaka, Y., Izumo, T., Izumi, F., Maekawa, T., Shibata, H., Nakano, A., Kishi, A., Akatani, K., and Kiso, Y. (2008) Antiallergic effects of Lactobacillus pentosus strain S-PT84 mediated by modulation of Th1/Th2 immunobalance and induction of IL-10 production. Int. Arch. Allergy Immunol. 145, 249-257.

24. Park, S. Y., Ji, G. E., Ko, Y. T., Jung, H. K., Ustunol, Z., and Pestka, J. J. (1999) Potentiation of hydrogen peroxide, nitric oxide, and cytokine production in RAW 264.7 macrophage cells exposed to human and commercial isolates of Bifidobacterium. Int. J. Food Microbiol. 46, 231-241.

25. Puertollano, E., Puertollano, M. A., Cruz-Chamorro, L., Alvarez de Cienfuegos, G., Ruiz-Bravo, A., and de Pablo, M. A. (2008) Orally administered Lactobacillus plantarum reduces pro-inflammatory interleukin secretion in sera from Listeria monocytogenes infected mice. Br. J. Nutr. 99, 819825.

26. Saarela, M., Mogensen, G., Fondén, R. Mättö, J., and Mat-
tila-Sandholm, T. (2000) Probiotic bacteria: safety, functional and technological properties. J. Biotechnol. 84, 197215.

27. Schreiber, R. D., Hicks, L. J., Celada, A., Buchmeier, N. A., and Gray, P. W. (1985) Monoclonal antibodies to murine gamma-interferon which differentially modulate macrophage activation and antiviral activity. J. Immunol. 134, 16091618.

28. Shin, M. S., Han, S. K. Ji, A. R., Ham, M. R., Kim, K. S., and Lee, W. K. (2007) Isolation and characteristics of bacteriocin-producing bacteria from the intestine of duck for probiotics. J. Anim. Sci. Technol. 49, 621-632.

29. Snyder, S. H., and Bredt, D. S. (1992) Biological roles of nitric oxide. Sci. Am. 266, 68-77.

30. Tejada-Simon, M. V., and Pestka, J. J. (1999) Proinflammatory cytokine and nitric oxide induction in murine macrophages by cell wall and cytoplasmic extracts of lactic acid bacteria. J. Food Prot. 62, 1435-1444.

31. Tsai, C. C., Liu, T. H., Chen, M. H., Tsai, C. C, and Tsen, H. Y. (2004) Toxicity evaluation for an Enterococcus faecium strain TM39 in vitro and in vivo. Food Chem. Toxicol. 42, 1601-1609.

32. van Furth, R., Cohn, Z. A., Hirsch, J. G., Humphrey, J. H., Spector, W. G., and Langevoort, H. L. (1972) The mononuclear phagocyte system: a new classification of macrophages, monocytes and their precursor cells. Bull. World Health Organ. 46, 845-852.

33. Wu, C. W., Yin, L. J., and Jiang, S. T. (2004) Purification and characterization of bacteriocin from Pediococcus pentosaceus ACCEL. J. Agric. Food Chem. 52, 1146-1151.

34. Zhang, X., Goncalves, R., and Mosser, D. M. (2008) The isolation and characterization of murine macrophages. Curr. Protoc. Immunol. Chapter 14, Unit 14.1.

(Received 2011.8.9/Revised 2011.10.4/Accepted 2011.10.10) 